\title{
The Relationship of Knowledge About Mastalgia With Anxiety Levels of Female Adolescents Aged 15-17 Years Who Experienced Mastalgia
}

\author{
Nur Azizah $^{1 *}$, Wiwik Muhidayati ${ }^{1}$, Rina Utami ${ }^{1}$, Tri Wulandari ${ }^{1}$ \\ ${ }^{a}$ Prodi SI Kebidanan dan Profesi Bidan Stikes Rajekwesi Bojonegoro, Jl Kh M Rosyid KM 5 Ngumpakdalem \\ Dander Kabupaten Bojonegoro. Telp (0353) 882197 \\ * Corresponding author \\ E-mail: aziezahmaulana@gmail.com
}

\begin{abstract}
Mastalgia is pain and dilation of the mammary glands before menstruation that was caused by edema and a relative increase in estrogen levels. The purpose of this research is to analyze the relationship of knowledge between adolescent knowledge and the level of anxiety of adolescents who experienced Mastalgia. This research method is correlational analytic with cross sectional approach. The population was an entire adolescent's female in July 2013 in Sumbertlaseh Village, Dander Subdistrict, Bojonegoro Regency as many as 253 sample students, and as many as 84 respondents. The sampling technique used purposive sampling: collecting data using a questionnaire, then through the process of editing, coding, scoring, and tabulating. While the results are presented in the form of images, tables and narrations. Then edited, coded, scored, tabulated and faced with Chi Square test. $\alpha<0.05)$, the research results are presented in the form of Figures, tables and narratives. Both variables were tested for significance by using cross table data analysis with a value of: 0.05 with a value obtained a value of 27.5> 0.05 so Ho is rejected, which means there is a relationship between knowledge about mastalgia and anxiety in adolescent female aged 15-17 years who experienced mastalgia at the Abu Dharin Islamic Boarding School, Sumberlaseh Village, Bojonegoro Regency. The conclusion of this study is that there is a relationship between knowledge about mastalgia and anxiety for adolescents aged 15-17 years who experience mastalgia at Boarding School Abu Dharin.
\end{abstract}

Keywords: Mastalgia, Knowledge, Anxiety, Female Adolescents.

\section{INTRODUCTION}

Mastalgia is pain and dilation of the mammary glands before menstruation that was caused by edema and hyperemia of the breast stroma(1). In female adolescent, the occurrence of breast pain may cause anxiety; especially if they lack the proper understanding related to the causes and how to treat them(2).
Based on data obtained from Sistem Informasi Rumah Sakit (SIRS-Hospital Information System) in Indonesia during 2011, adolescents with complaints of breast pain experienced a significant increase as many as 1.502 . Those number consists of criteria for adolescents aged 11-24 years as many as 45 people, while those aged $25-44$ years as many as 673 people. And the age of 
more than 45 years as the rest still ranks first in the number of breast cancer patients(3). According to Dr. Miriam Stoppard, 60\% of women were known to suffer from some sort of breast discomfort, such as pain (mastalgia) in one or both breasts (4). Based on an initial survey conducted by researchers at the $\mathrm{Abu}$ Dharrin Islamic Boarding School in January 2013 on 8 students, it is known that 5 people $(62.5 \%)$ have experienced breast pain, especially before menstruation.

Anxiety that occurs among the adolescents are caused by lack of understanding regarding a phenomenon; that breast pain is due before menstruation, and many female adolescents experienced such. Many breast pain encounters were commonly related with menstrual cycle, and fluctuations in hormone levels in which, some women experienced as a part of it. Pain may also correspond to the sensitivity of the breast tissue against hormones, and this may vary in the same breast or between breasts. But hormones are not everything, since for the majority of women, pain is felt more heavily in one breast than the other. Most women experience varying degrees of pain when their breasts become sensitive right before their period. However, some women may experience pain starting at ovulation, in the mid-cycle, and continues for two weeks until menstruation occurs. Other women may find this premenstrual pain worse after the birth of their first child (5).

Efforts that may reduce the pain during mastalgia is handled through a proper care. For example, take a "pain-reducing" medicine of paracetamol or ibuprofen. One also may choose the proper wearing for such condition that could support the breast (sports-bra), using a cold press to treat swollen breast, and hot compounds to relieve pain and reduce consumption of foods that contain lots of salt. For pain in the breast that lasts for a long time (more than 1 month) or does not go away with painkillers, you should consult a doctor(6).

\section{RESEARCH METHODS}

This type of research uses analytic correlation with a cross-sectional approach with a population of all female adolescents aged 15-17 years who experience mastalgia at the Abu Dharin Islamic Boarding School, Bojonegoro Regency in 2013 as many as 253 respondents with a total sample of 84 respondents, exclusion criteria in this study: students who are not willing to sign the informed consent. students who do not experience mastalgia, students who are less than 14 years old or more than 18 years old.

The study was conducted in 2020 at the Abu Dharin Islamic Boarding School, Bojonegoro Regency. The independent variable is the knowledge of adolescent girls about mastalgia and the dependent variable is the level of anxiety of adolescents who experience mastalgia. Data was collected using a questionnaire and data processing and statistical tests were carried out using the Chi Square test with $p=0.05$. data presentation using cross tabulation.

\section{RESULTS}

These are the research results on the relationship between adolescent knowledge/awareness about mastalgia and adolescent anxiety who experience mastalgia at the Abu Dharin Islamic Boarding School Bojonegoro in 2020

1. Female adolescents' knowledge (aged 15-17) regarding the matter of mastalgia at the Abu Dharin Islamic Boarding School Bojonegoro in 2020

Table 1. Distribution of female adolescents' knowledge regarding mastalgia

\begin{tabular}{|c|c|c|c|}
\hline No & $\begin{array}{c}\text { Female } \\
\text { Adolescent } \\
\text { Knowledge } \\
\text { Related With } \\
\text { Mastalgia }\end{array}$ & $\mathrm{F}$ & $\begin{array}{c}\text { Percentage } \\
(\%)\end{array}$ \\
\hline 1 & Excellent & 19 & 22,6 \\
\hline 2 & Fair & 47 & 55,9 \\
\hline \multirow{2}{*}{3} & Subpar & 18 & 22.7 \\
\hline & Sum & 84 & 100 \\
\hline
\end{tabular}

Source: Primary data research in 2020 
Based on the table, majority of female adolescents possess adequate knowledge related to mastalgia, counted as much as $77,4 \%$.

2. Levels of female adolescents' anxiety (aged 15-17) at the Abu Dharin Islamic Boarding School Bojonegoro in 2020.

Table 2. Distribution of female adolescents' anxiety.

\begin{tabular}{llcc}
\multicolumn{4}{c}{ adolescents' anxiety. } \\
Nemale & & \\
No & $\begin{array}{c}\text { Adolescent } \\
\text { Levels of } \\
\text { Anxiety }\end{array}$ & F & $\begin{array}{c}\text { Percentage } \\
(\%)\end{array}$ \\
& Mild & 62 & 73,8 \\
\hline 1 & Fair & 19 & 22,6 \\
2 & Severe & 3 & 3,6 \\
3 & Sum & 84 & 100 \\
& Sum
\end{tabular}

Source: Primary data research in 2020

Based on table 2, half of the respondents experienced anxiety during mastalgia.

3. Cross-tabulation of the relationship between knowledge about mastalgia and the level of anxiety of female adolescent aged 15-17 years who experience mastalgia at the Abu Dharin Bojonegoro Islamic Boarding School in 2020.

Table 3. Cross tabulation of the relationship between knowledge and the level of anxiety of adolescent girls at the Abu Dharin Bojonegoro Islamic Boarding School in 2020

\begin{tabular}{llcccccccc}
\hline No & Knowledge & \multicolumn{4}{c}{ Anxiety } & \multicolumn{3}{c}{ Total } \\
& & \multicolumn{2}{c}{ Mild } & \multicolumn{2}{c}{ Fair } & \multicolumn{2}{c}{ Severe } & & \\
& & f & $\%$ & f & $\%$ & f & $\%$ & f & $\%$ \\
\hline 1 & Excellent & 17 & 20, & 1 & 1,2 & 1 & 1,2 & 19 & 22, \\
& & & 2 & & & & & & 6 \\
2 & Fair & 31 & 36, & 16 & 19 & 0 & 0 & 47 & 55, \\
& & & 9 & & & & & & 9 \\
3 & Subpar & 14 & 16, & 2 & 2,4 & 2 & 2,4 & 18 & 22, \\
& & & 7 & & & & & & 7 \\
& Total & 62 & 73, & 19 & 22, & 3 & 3,6 & 84 & 100 \\
& & & 8 & & 6 & & & & \\
\hline
\end{tabular}

Source: Primary data research in 2020

Based on research table 3 , female adolescents with adequate knowledge encountered mild anxiety; were 32 respondents $(36,9 \%)$

To discover the relationship between adolescent knowledge about mastalgia and the level of anxiety of female adolescent at the Abu Dharin Bojonegoro Islamic Boarding School in 2020, a Chi-Square statistical test was carried out with the Phi coefficient. The results of the Chi-Square test with the SPSS 16 program obtained the results of the chi-square value $=1.03$, this value is at a significant level of 0.711; because of the Asym value. Sig. (2-sided) < significant level $(p=0.05)$, then $\mathrm{H} 0$ is rejected (7), which means that there is a relationship between adolescent knowledge about mastalgia and the anxiety level of adolescent girls at Boarding School Abu Dharin Bojonegoro.

\section{DISCUSSION \\ 1. Female Adolescent Knowledge \\ Knowledge is a vital domain that took} part in shaping one's action and thought. This study has shown that one's behaviour based on knowledge, was more proper and everlasting than the other way around (8).

Mastalgia is a pain in the breast. This pain varied greatly based on the menstrual cycle (9). Breast pain that occurs may cause anxiety to certain degree. Furthermore the conditions may worsen if a person lack the knowledge of one's particular affair, and how to deal with it (10)

Many women with mastalgia feel more threatened by cancer than the pain itself. Mastalgia has a decreased ratio of progesterone to estrogen in the second half of the menstrual cycle. Abnormalities in the hormone prolactin can affect breast tenderness. Hormones can also affect the cycle of breast pain as a result of stress. Breast pain can increase or change patterns with hormonal changes that occur during times of stress (11).

Majority of the adolescents with sufficient level of knowledge, according to the theory; this period is a period in which adolescents learn to think independently and make their own decisions, feeling the need to gather new experiences, and intellectually more developed and curious about many things, being able to think abstractly allows adolescents to think hypothetically. This made them willing to receive information 
obtained from education, mass media and the surrounding community, so that they can increase their knowledge regarding mastalgia.

\section{Levels of Female Adolescents Anxiety}

Anxiety is a mental disturbance; characterized by the presence of constant fear, resulting in the failure of assessing reality. Although one may retain it's personality intact, change in behavior can be a possibility but still within the limits of norms.

It was discovered that most of them, whom were teenagers with mild anxiety levels (due to sufficient knowledge about mastalgia), that considers mastalgia was a natural thing. Their anxiety were individual's subjective experience of the tensions, difficulties and pressures. In young women, breast pain that occurs can cause anxiety in the situation they are experiencing, especially if they do not understand the causes and how to overcome them.

Anxiety is a disturbance in feelings characterized by feelings of fear or worry that are deep and ongoing, do not experience disturbances in assessing reality, personality is still intact, behavior can be disturbed but still within normal limits. (12). It was found that most of them were teenagers with mild anxiety levels, due to sufficient knowledge of young women about mastalgia, so they thought that mastalgia was a natural thing.

Adolescent women's anxiety is an individual's subjective experience of the tensions, difficulties and pressures that accompany a conflict or threat. In young women, breast pain that occurs can cause anxiety in the situation they are experiencing, especially if they do not understand the causes and how to overcome them (13)

\section{The Relationship of Knowledge with Anxiety Levels of Female Adolescent Experiencing Mastalgia}

Majority of the respondents (from 84 female teenagers) possess adequate knowledge, accompanied by mild level anxiety (total up to $36,9 \%$ ). Breast is part of the genital system whose development, maturation, and differentiation are influenced by hormones and growth factors that act at the stromal and epithelial cell levels (1). Many women with mastalgia felt more vulnerable to the threat of cancer than the pain it caused. Mastalgia has a decreased ratio of progesterone to estrogen in the second half of the menstrual cycle. Abnormalities in the hormone prolactin can affect breast pain. Hormones can also affect the cycle of breast pain as a result of stress. Breast pain can increase or change patterns with hormonal changes that occur during times of stress.

Anxiety is a symptom that often occurs and is very striking at menarche events which is then reinforced by the desire to reject the physiological process. This anxiety is caused by the ignorance of young women about the physiological changes that occur during adolescence so that menstruation is considered a bad thing. Mental readiness and lack of knowledge about self-care needed during menstruation (14).

The results of this study are in accordance with the theory above, where out of 84 respondents, most of them were teenagers with sufficient knowledge about mastalgia with mild anxiety levels. This is due to the lack of information about mastalgia, resulting in psychological symptoms such as tension, sensitivity, irritability, depression, lethargy and feelings of anxiety (1).

The results of this study are in accordance with the theory above, where out of 84 respondents, most of the respondents were teenagers with a sufficient level of knowledge about mastalgia with a mild level of anxiety. This is due to a lack of information about mastalgia, which results in psychological symptoms such as sensitivity, irritability, depression, lethargy and feelings of anxiety.

Not all individuals are able to accept changes during adolescence, especially when facing menarche, one of which is 
anxiety. Information on KRR, especially regarding menstruation, must be true, because menstruation is a very important event for young women which is a sign of sexual maturity and is closely related to reproductive function (15).

\section{CONCLUSION}

The research above shown, that there is a relationship between adolescent knowledge about mastalgia and the level of anxiety of female adolescents at Boarding School Abu Dharin Bojonegoro. Most of the adolescent's knowledge is sufficient and experiences mild anxiety when experiencing mastalgia.

\section{REFERENCES}

1. Prawirohardjo S. (2013) Ilmu Kebidanan. Jakarta: Yayasan Bina Pustaka.

2. Murshid KR. (2011). A review of mastalgia in patients with fibrocystic breast changes and the non-surgical treatment options. J Taibah Univ Med Sci

3. Kemenkes. Juknis SIRS 2011: Sistem Informasi Rumah Sakit. Direktorat Jenderal Bina Upaya Kesehat.

4. Kusmiran Sibagarian (2013). Kesehatan Reproduksi Wanita. Jakarta: Trans Info Media.

5. Dwi Andhayani Kartikaputri KW (2013). MASTALGIA. E-Jurnal Udayana Med.

6. Syaiful Y, Aristantia R. (2016). Pendidikan Kesehatan Pemeriksaan Payudara Sendiri Terhadap Perilaku Sadari Pada Remaja (Health Education Breast Self Examination Toward Bse Behavior In Adolescent). Journals Ners Community.

7. Nursalam (2011). Konsep Dan Penerapan Metodologi Penelitian Ilmu. Jakarta: Salemba Medika.

8. Notoatmodjo S. Ilmu Perilaku
Kesehatan. Jakarta: Rineka Cipta; 2014.

9. Nugroho T (2011). Asuhan Keperawatan Maternitas, Anak, Bedah, Penyakit Dalam. Yogyakarta: Nuha Medika

10. Ignatia Dimarda Pamintaningtiyas $1 \mathrm{CHS}$ (2020) Peran Regulasi Emosi dan Dukungan Sosial, Pasangan terhadap Kecemasan pada Primigravida Trimester Ketiga. J Psikol Konseling Vol 16 No 1.

11. Sukmadewi M (2016). Gambaran Tingkat Kecemasan Pada Ibu Hamil Dalam Menghadapi Persalinan Di Desa Tualang Teungoh Kecamatan Langsa Kota Kabupaten Kota Langsa

12. Siyamti S, Pertiwi HW (2011). Hubungan Antara Tingkat Kecemasan dengan Sindrom Premesntruasi pada Mahasiswi Tingkat II Akademi Kebidanan Estu Utomo Boyolali. J Kebidanan Akbid Estu Utomo

13. Khairah H, Milvita D, Fitriyani D, Mulyadi S, Nazir F. (2019) Gambaran Kecemasan dan Depresi Wanita dengan Kanker Payudara. Muara Ilmu Sos Hum dan Seni.

14. Asni A, Dwihestie LH (2019) The effect of reproductive health counseling on readiness of managing menarche. $\mathrm{J}$ Heal Technol Assess Midwifery.

15. Kartono K. (2008). Psychology of Women 1 Getting to know Adolescent Girls and Adult Women. Bandung: Mandar Maju 